\title{
HUBUNGAN ANTARA PENGETAHUAN, PENDIDIKAN IBU DENGAN PENANGANAN BALITA USIA 6 - 12 BULAN YANG MENDERITA DIARE
}

\author{
Zulfa Ayu Deviazka ${ }^{1}$, Ragil Setiyabudi ${ }^{2}$ \\ 1, 2 Fakultas Ilmu Kesehatan, Universitas Muhammadiyah Purwokerto \\ Email: ayu.zulfa96@gmail.com ${ }^{1}$, gilsra@yahoo.com²
}

\begin{abstract}
Abstrak:
Diare merupakan suatu keadaan abnormal dari pengeluaran tinja dengan frekuensi tiga kali atau lebih dengan melihat konsisten lembek, cair sampai dengan atau tanpa darah dan lendir. Ibu balita adalah orang yang pertama kali menangani, jika balita tersebut mengalami diare. Tujuan penelitian ini adalah untuk mengetahui hubungan antara pengetahuan dan pendidikan ibu dengan penanganan diare balita usia 6-12 bulan. Jenis penelitian adalah deskriptif kuantitatif dengan menggunakan pendekatan cross sectional. Populasi dalam penelitian ini adalah ibu yang mempunyai balita usia 6-12 bulan. Teknik sampling yang digunakan dalam penelitian ini adalah total sampling sebanyak 30 responden. Analisis yang digunakan uji statistik chi square dengan tingkat kemaknaan $(\alpha)$ 0,05 . Pada penelitian ini di dapatkan hasil Pengetahuan ibu dengan penanganan diare baik sebesar $60 \%$, dan tingkat pendidikan ibu paling tinggi adalah pendididikan dasar dengan penanganan diare sebesar $60 \%$, Uji chi square diperoleh $p=0,0001$, artinya ada hubungan pengetahuan, pendidikan ibu dengan penanganan diare pada balita usia 6-12 bulan, di dapatkan kesimpulan bahwa hasil pengetahuan pendidikan dengan penanganan diare saling berhubungan dan diperoleh pengetahuan baik sebesar $60 \%$ dan ibu balita mayoritas berpendidikan tingkat dasar sebesar $60 \%$ dan penanganan diare dalam kategori baik sebesar $53,33 \%$.
\end{abstract}

Kata Kunci: Diare, Ibu Balita, Pengetahuan, Pendidikan, Penanganan

\begin{abstract}
Diarrhea was abnormal condition of feces with three times or more excretion by considering of flaccid consistency, slushy, and with or withour blood and phlegm. Toddler mother was the first helper when the baby had the diarrhea. The study was aimed to find out the relation of the knowledge and mother's education in handling the diarrhea to a baby with the age of 6-12 months. A descriptive quantitative method was the type of this research with cross sectional approach. The population of this study were mothers who had baby with the age of 6-12 months. The sample was 30 respondents. The analysis used was statistic examination chi square with value level that was $(\alpha) 0,05$. The results showed that the knowledge of mothers of handling the diarrhea was $60 \%$ (good) and the level of education was elementary school with the treatment of it was $60 \%$ as well. Chi square test was $p=0,0001$ which indicated that there was a relation of knowledge and education of mothers in handling diarrhea. It concluded that the knowledge of education had something to do with the diarrhea treatment. It could claim that the treatment of diarrhea was a good category (53.33\%).
\end{abstract}

Key words: Diarrhea, Education, Knowledge, Treatment, Toddler Mother 


\section{PENDAHULUAN}

Diare adalah buang air besar (defekasi) dengan tinja berbentuk cair atau setengah cair (setengah padat), kandungan air tinja lebih banyak dari biasanya lebih dari $200 \mathrm{~g}$ atau $200 \mathrm{ml} / 24$ jam. Definisi lain memakai kriteria frekuensi, yaitu buang air besar encer lebih dari 3 kali per hari. Buang air besar encer tersebut dapat/tanpa disertai lendir dan darah. Penyakit diare sampai saat ini masih merupakan salah satu penyebab utama kesakitan dan kematian dan diare masih menjadi masalah penyakit kesehatan masyarakat di negara berkembang seperti di indonesia, karena morbilitas dan mortalitasnya yang masih sangat tinggi terjadi. Diare pada bayi cukup berbahaya, karena dapat menimbulkan kematian bayi maupun balita serta angka kejadian cukup tinggi setiap tahunnya. Lima juta anak berusia kurang dari lima tahun meninggal akibat diare (Maharani, 2016).

Data World Health Organization (WHO) di Indonesia mengungkapkan, bahwa Diare adalah keluarnya 3 atau lebih feses yang longgar atau cair per hari, atau lebih sering daripada yang normal untuk individu. Ini biasanya merupakan gejala infeksi gastrointestinal, yang dapat disebabkan oleh berbagai organisme bakteri, virus, dan parasit. Infeksi menyebar melalui makanan atau air minum yang terkontaminasi, atau dari orang ke orang sebagai akibat dari kebersihan yang buruk. Diare parah menyebabkan kehilangan cairan, dan mungkin mengancam jiwa, terutama pada anak-anak kecil dan orang-orang yang kekurangan gizi atau memiliki gangguan kekebalan. (Slamet suyono 2016), Diare tidak hanya terjadi di negara berkembang tapi juga di negara maju, di negara maju walaupun sudah terjadi perbaikan ekonomi dan kesehatan namun kasus diare tetap tinggi, Di negara Berkembang diare menyebabkan kematian 3 juta penduduk setiap tahunnya (Darmawati, 2012).

Hasil dari Riskesdas tahun 2016 ,2017, dan 2018 menunjukan bahwa prevalensi kasus Diare pada balita di Jawa Tengah Sebesar 68,9\%, 55,8\% ,75,6\% merupakan jumlah kejadian diare pada Balita. (Kemenkes RI,2018) ,Kasus diare pada anak di Kabupaten Brebes sendiri yang menempati urutan ke enam dengan kasus diare tertinggi di Jawa Tengah. Berdasarkan jenis kelamin, kasus terbanyak terjadi pada Balita perempuan usia $6-12$ bulan yaitu sebesar 57,5\%, hal ini disebabkan bahwa balita perempuan lebih banyak berhubungan dengan faktor risiko diare.(Dinkes Provinsi Jateng, 2018.). 
Hasil Riskesdas Kabupaten Brebes menunjukkan prevensi kejadian diare pada balita usia 6-12 bulan dari tahun 2016, 2017, 2018 adalah 20,94\%, 68,15\% dan 79,8\% (Dinkes Brebes, 2019). Kasus kejadian diare pada balita usia 6-12 bulan di wilayah Kabupaten Brebes menduduki peringkat pertama dari 4 puskesmas yang ada di Kabupaten Brebes. Puskesmas Kelurahan Brebes khususnya tahun 2018 menunjukkan prevalensi sebesar 79,8\%, angka ini belum mencapai target yang diharapkan yaitu 90\% (Dinkes Brebes, 2019). Beberapa faktor yang menjadi penyebab terjadinya diare pada balita usia 6-12 bulan di antaranya: faktor infeksi , malabsorbsi dan faktor makanan, serta beberapa faktor yang memengaruhi diare meliputi faktor lingkungan, faktor perilaku, faktor pengetahuan ibu, faktor Gizi ,dan faktor sisial ekonomi (Suharyono, 2011). Faktor lingkungan yang paling dominan yaitu sarana air bersih dan pembuangan tinja. Kedua faktor ini berinteraksi dengan perilaku manusia yang tidak sehat pula, sehingga penularan diare dengan mudah dapat terjadi (Depkes,2016).

Praktek penanganan diare oleh ibu balita merupakan titik kritis dalam penanggulangan diare pada balita. Hal ini dikarenakan bahwa balita merupakan usia emas dalam tumbuh kembang anak. Praktek atau perilaku ibu balita dapat dipengaruhi oleh banyak faktor. Tujuan penelitian ini adalah untuk mengetahui hubungan antara pengetahuan dan pendidikan ibu dengan penanganan diare balita balita usia 6-12 bulan.

\section{KAJIAN PUSTAKA}

Diare adalah keadaan frekuensi buang air besar lebih dari 4 kali pada bayi dan lebih dari 3 kali pada anak dengan konsistensi feses encer, dapat berwarna hijau atau dapat pula bercampur lendir dan darah atau lendir saja (Kementrian Kesehatan RI, 2011). Dua kriteria penting harus ada yaitu BAB (Buang Air Besar) cair dan sering. Apabila buang air besar sehari tiga kali tapi tidak cair, maka tidak bisa disebut diare, begitu juga apabila buang air besar dengan tinja cair tapi tidak sampai tiga kali dalam sehari, maka itu bukan diare. Pengertian Diare didefinisikan sebagai inflamasi pada membran mukosa lambung dan usus halus yang ditandai 
dengan muntah-muntah yang berakibat kehilangan cairan dan elektrolit yang menimbulkan dehidrasi dan gangguan keseimbangan elektrolit.

Pada saat diare, terjadi proses peningkatan motilitas atau pergerakan usus untuk mengeluarkan kotoran atau racun. Anti diare akan menghambat proses tersebut sehingga tidak boleh diberikan pada bayi dan anak. Pemberian anti diare pada bayi dan anak justru dapat menimbulkan komplikasi berupa prolapsus pada usus yang membutuhkan tindakan operasi. Ibu dan pengasuh bayi yang berhubungan erat dengan pasien harus diberikan edukasi mengenai cara pemberian oralit, zinc sulfat, ASI (Air Susu Ibu) dan makanan, serta tanda-tanda kapan pasien harus segera dibawa lagi ke tempat pelayanan kesehatan, yaitu: BAB cair lebih sering, muntah berulang-ulang, mengalami rasa haus yang nyata, makan atau minum sedikit, demam, tinja berdarah, dan keluhan diare tidak membaik dalam waktu 3 hari. Pencegahan diare dapat dilakukan dengan memberikan SI eksklusif selama 6 bulan dan diteruskan sampai usia 2 tahun, memberikan Makanan Pendamping ASI (MP-ASI) sesuai umur, menggunakan air bersih yang cukup, mencuci tangan dengan air dan sabun sebelum makan dan sesudah BAB, BAB di jamban, membuang tinja bayi dengan benar, memberikan imunisasi campak. Pemberian vaksin Rotavirus juga dapat dilakukan dimana rekomendasi Ikatan Dokter Anak Indonesia (IDAI) tahun 2014 menganjurkan pemberian vaksin Rotavirus saat anak berusia 2, 4, dan 6 bulan.

\section{METODE PENELITIAN}

Jenis penelitian adalah deskriptif kuantitatif dengan menggunakan pendekatan cross sectional. Populasi dalam penelitian ini adalah ibu yang mempunyai balita usia 6-12 bulan. Teknik sampling yang digunakan dalam penelitian ini adalah total sampling sebanyak 30 responden. Analisis yang digunakan uji statistik chi square dengan tingkat kemaknaan 0,05. Instrumen penelitian ini menggunakan kuesioner yang menggali tentang pendidikan, pengetahuan dan penanganan diare oleh ibu balita. 
Variabel independen dalam penelitian ini adalah penanganan diare pada Balita, sedangkan variabel dependen dalam penelitian ini adalah pengetahuan dan pendidikan ibu balita.

\section{HASIL DAN DISKUSI}

\section{Karakteristik Responden}

Dari hasil penelitian yang telah dilakukan diperoleh data terkait karakteristik responden seperti tabel 1

\section{Tabel 1}

Distribusi Frekuensi Karakteristik faktor Pengetahuan, Pendidikan dengan penanganan diare di wilayah kerja Puskesmas Brebes $(n=30)$

\begin{tabular}{lll}
\hline Variabel & Frekuensi (n) & Persentase (\%) \\
\hline Pengetahuan & & \\
Kurang & 12 & 40 \\
Baik & 18 & 60 \\
\hline Pendidikan & \\
Dasar & 18 & 60 \\
Menengah dan tinggi & 12 & 40 \\
\hline Penanganan & 14 & 46,7 \\
Kurang baik & 16 & 53,3 \\
Baik & 30 & 100 \\
\hline Total & Sumber: Data Primer 2020
\end{tabular}

Tingkat pengetahuan ibu balita mayoritas pada kategori baik sebesar $60 \%$. Tingkat pendidikan ibu balita mayoritas pada tingkat dasar sebesar $60 \%$. Tingkat penanganan diare mayoritas pada kategori baik sebesar 53,3\% (tabel 1). 


\section{Deskripsi Variabel Penelitian}

Tabel 2

Distribusi Frekuensi Tingkat Pengetahuan ibu terhadap Balita usia 6-12 yang mengalami diare di wilayah kerja Puskesmas Brebes $(n=30)$

\begin{tabular}{lcccccccc}
\hline \multirow{2}{*}{ Variabel } & \multicolumn{3}{c}{ Penanganan diare } & Total & $\begin{array}{c}p \\
\text { value }\end{array}$ & OR (CI 95\%) \\
\cline { 2 - 9 } Pengetahuan & $\mathrm{n}$ & $\%$ & $\mathrm{n}$ & $\%$ & $\mathrm{n}$ & $\%$ & 0,011 & $\begin{array}{c}2,7 \\
\text { Kurang baik }\end{array}$ \\
\cline { 2 - 9 } & 9 & 75 & 3 & 25 & 12 & 100 & & \\
\hline Kurang baik & 5 & 27,8 & 13 & 72,2 & 18 & 100 & \\
\hline Baik & 14 & 46,7 & 16 & 53,3 & 30 & 100 & & \\
\hline Total & \multicolumn{7}{c}{ Sumber: data primer 2020}
\end{tabular}

Tabel 2 menunjukkan bahwa tingkat pengetahuan ibu yang kurang baik dengan penanganan diare kurang baik (75\%) lebih besar dibandingkan pengetahuan ibu yang baik dengan penanganan diare kurang baik $(27,8 \%)$. Pengetahuan ibu yang kurang baik dengan penanganan diare yang baik (25\%) lebih kecil dibandingkan pengetahuan ibu yang baik dengan penanganan diare yang baik $(72,2 \%)$

Ibu yang berpengatahuan kurang baik dengan penanganan diare yang baik sebanyak seperempat dari populasi dan ibu berpengetahuan baik dengan penanganan diare kurang baik lebih dari seperempat populasi dikarenakan $40 \%$ ibu balita berpendidikan menengah. Penanganan diare juga merupakan manifestasi praktek ibu balita yang terbentuk dari pendidikan, pengalaman, penyerapan informasi tentang diare yang datang dari luar ibu balita.

Hasil $\mathrm{p}$ value chi square sebesar $0,011(<0,05)$ menunjukkan bahwa tingkat pengetahuan ibu balita berhubungan dengan penanganan diare. Nilai OR(95\%CI) sebesar 2,7(1,197-6,090) mengandung arti bahwa ibu balita yang berpengatahuan kurang baik perpeluang 2,7 kali menangani diare balitanya dengan cara kurang baik daripada ibu balita yang berpengetahuan baik.

Ibu balita berpengetahuan baik tentang faktor risiko terjadinya dehidrasi pada balita dengan diare lebih dari setengah dari populasi. Informasi yang diperoleh ibu balita dari pendidikan formal dan nonformal dapat memberikan pengaruh jangka pendek (immediate impact) sehingga menghasilkan perubahan dan proses pengetahuan (Budiman \& Riyanto, 2013). Menurut Muliadi (2011), seseorang dengan sumber informasi yang banyak dan beragam akan menjadikan orang 
tersebut memiliki pengetahuan yang luas, sumber informasi yang didapatkan seseorang bisa untuk mendapatkan pengetahuan, Altriza Juliyandari, dkk (2017). Berdasarkan hasil penelitian menunjukan terdapat 25 anak dengan MP ASI dini yang menderita diare. Hasil penelitian tersebut menyatakan masih banyak ibu yang memberikan MP ASI dini karena menurut keyakinan yang ada dalam keluarga anak yang mendapat MP ASI lebih cepat akan lebih kuat. Hal ini konsisten dengan penelitian Altriza Juliyandari, dkk (2017), yang menerangkan bahwa ada hubungan yang signifikan antara pengetahuan ibu dalam pemberian MP-ASI dini dengan pertumbuhan bayi usia $6-24$ bulan $(p=0,045, p<0,05)$. Hambatan utama tercapainya ASI eksklusif dan pemanfaatan MP-ASI yang benar.

Tabel 3

Distribusi Frekuensi Tingkat Pendidikan ibu terhadap Balita usia 6-12 yang mengalami diare di wilayah kerja Puskesmas Brebes $(n=30)$.

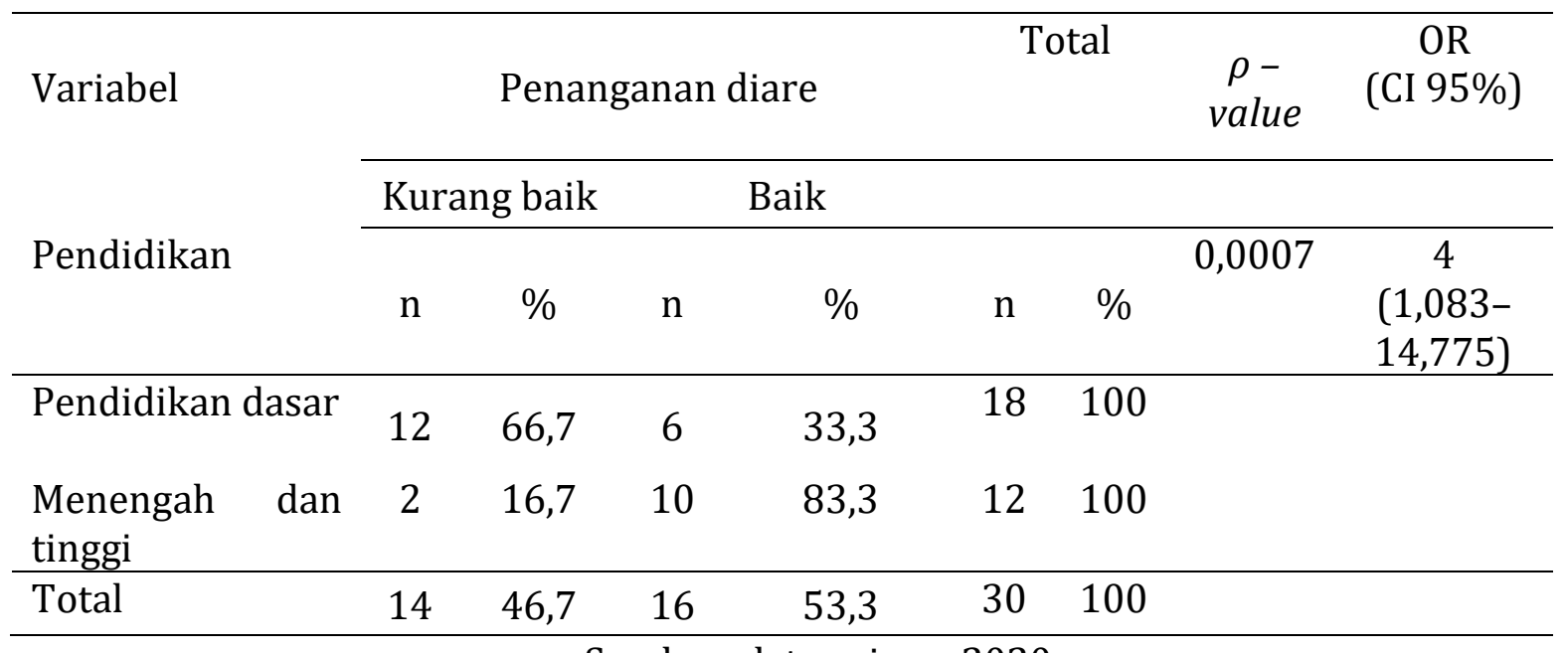

Sumber: data primer 2020

Tabel 3 menunjukan bahwa ibu balita berpendidikan dasar dengan penanganan diare kurang baik (66,7 \%) lebih besar daripada ibu balita yang berpendidikan menengah dan tinggi dengan penanganan diare kurang baik $(16,76$ $\%)$. Ibu balita berpendidikan dasar dengan penanganan baik $(33,3 \%)$ lebih kecil dibandingkan ibu balita pendidikan menengah dan tinggi dengan penanganan diare yang baik $(83,3 \%)$.

Nilai $\rho$-value chi square sebesar $0,007(<0,05)$ dapat diartikan bahwa secara statistik terdapat hubungan pengetahuan pendidikan ibu balita dengan 
penanganan diare pada balita usia 6-12 bulan di wilayah Puskesmas Brebes. Hasil analisis juga didapatkan $\mathrm{OR}=4(1,083-14,775)$ yang dapat diartikan bahwa ibu balita yang berpendidikan dasar berpeluang 4 kali mengalami penanganan diare yang kurang baik daripada ibu balita yang berpendidikan menengah dan tinggi. Semakin tinggi tingkat pendidikan seseorang maka kemampuannya dalam memahami suatu informasi dan menangkapnya menjadi pengetahuan semakin meningkat. Hasil penelitian ini menunjukan bahwa tingkat pendidikan ibu balita mayoritas pada pendidikan dasar pada kategori penanganan diare kurang baik . Menurut Nursalam (2011) tingkat pendidikan adalah level atau tingkat suatu proses yang berkaitan dalam mengembangkan semua aspek kepribadian manusia, yang mencakup pengetahuan, nilai, sikap, serta keterampilan. Purwati (2013) mengemukakan bahwa pendidikan dapat mempengaruhi proses belajar, semakin tinggi pendidikan seseorang semakin mudah seseorang untuk menerima informasi. Dengan pendidikan yang baik maka seseorang akan cenderung untuk mendapatkan informasi, baik dari orang lain maupun media masa pendidikan merupakan suatu tindakan untuk membimbing seseorang menuju suatu tujuan tertentu.

\section{KESIMPULAN}

Berdasarkan hasil penelitian dan pengolahan data dapat ditarik kesimpulan bahwa pada tingkat pengetahuan ibu yang baik menggambarkan keadaan yang terkait dengan Tingkat Pendidikan menengah yaitu sebesar (40\%) dan pada Tingkat Penanganan baik pada balita diare sebesar $(35,3 \%)$ menunjukkan bahwa pendidikan responden pada tingkat dasar sebesar (60\%) lebih tinggi dibandingkan dengan tingkat pendidikan yang lainnya, dan pada tingkat penanganan baik pada balita diare sebesar (35,3\%). Terdapat hubungan antara tingkat pengetahuan ibu dengan penanganan diare pada balita usia 6-12 bulan. Terdapat hubungan antara tingkat pendidikan ibu dengan penanganan diare pada balita usia 6-12 bulan. 


\section{DAFTAR PUSTAKA}

Christie G. Turin \& Theresa J. (2014).The Role of Maternal Breast Milk in Preventing Infantile Diarrhea in the Developing World.Currn Trop Med Rep (2014) 1;97-105

Darmawati. (2012).Faktor-faktor yang berhubungan dengan kejadian diare pada masyarakat dikelurahan puncak indah kecamatan malili kabupaten luwu timur. Jurnal kesehatan 2012.

Dinas Kesehatan Kota Surakarta.(2017). Profil Kesehatan Kota Surakarta.http://www.depkes.go.id/resources/download/profil/PROFIL KAB KOTA20 14/3372 Jateng Kota Surakarta 2017.pdf.

Darmawati. (2012).Faktor-faktor yang berhubungan dengan kejadian diare pada masyarakat .Jurnal kesehatan 2012.

Departemen Kesehatan Republik Indonesia. (2016). Buku Bagan Manajemen Terpadu Balita Sakit. Jakarta: Depkes RI

Departemen Kesehatan Republik Indonesia. (2016). Buku Bagan Manajemen Terpadu Balita Sakit. Jakarta: Depkes RI

Dinas Kesehatan Provinsi Jawa Tengah. (2018), Dinas Kesehatan Provinsi Jawa Tengah, Semarang 2018, Profil Kesehatan Provinsi Jawa Tengah Tahun 2018, Dinas Kesehatan Provinsi Jawa Tengah, Semarang, 2018, , Dinas Kesehatan Provinsi Jawa Tengah, Semarang.

Dinkes Brebes. (2019). Profil Kesehatan Kabupaten Brebes 2018. Brebes : DKK Brebes

Hanieh et. Al. (2015). Exclusive Breast Feeding in Early Infancy Reduces the Risk of Inpatient Admission for Diarrhea and Suspected Pneumonia in Rural Vietnam : A Prospective Cohort Study. BMC Public Health (2015)15:1166

Juliyandri,Altriza, dkk. (2017) yang berjudul "Hubungan karakteristik ibu dan perilaku dalam pemberian MP ASI dini dengan pertumbuhan bayi usia 0- 6 bulan"Jurnal Kesehatan Masyarakat (e-Journal)Volume 6, Nomor 4, Agustus 2018 (ISSN:2356- 3346) http://ejournal3.undip.ac.id/index.php/jkm

Kementrian Kesehatan RI.(2011). Profil Kesehatan Indonesia 2010.Jakarta: Kemenkes RI 
Kementrian Kesehatan RI. (2017). Profil Kesehatan Indnesia Tahun 2016. Jakarta: Kementrian Kesehatan Republik Indonesia.

Laura M Lamberti \& Christa L Fischer Walker. (2011). Breastfeeding and the risk for diarrhea morbidity and mortality.Department of International Health, Johns Hopkins Bloomberg School of Public Health, Baltimore, MD, USA.BMC Public Health 2011, 11 (Suppl 3):S15

Molla Gedefaw \& Resom Berhe. (2015). Determinates of Childhood Pneumonia and Diarrhea with Special Emphasis to Exclusive Breastfeeding in North Achefer District, Northwest Ethiopia : A Case Control Study. Open Jounal Epidemiology,2015,5,107-112

Notoadmodjo, S. (2010).Metodologi Penelitian Kesehatan. Jakarta: Rineka Cipta

Panda, S at all. (2014). Factors associated with darrhoea in young children and incidence of symptomatic rotavirus infection in rural.Epidiomologi.Infect.(2014),142, 1848-1858.

Riset Kesehatan Dasar (RISKESDAS). 2007. Jakarta: Badan Penelitian dan Pengembangan Kesehatan, Departemen Kesehatan, Republik Indonesia.

Sucianingsih, H, dkk. (2018)“Faktorpredisposisi yang mempengaruhi perilaku ibu dalam pemberian makanan pendamping ASI dini" Dunia Keperawatan, Volume 6, Nomor 2, September 2018: 116-122.

Sulastri, \& Murningsih. (2015 ).Hubungan Antara Pemberian Makanan Tambahan Pada Usia Dini Dengan Tingkat Kunjungan Ke Pelayanan Kesehatan Dikelurahan Sine Sragen. Berita Ilmu Keperawatan issn 1979-2697, Vol.1 No.3,Dosen Keperawatan FIK Universitas Muhammadiyah Surakarta.

WHO. (2017). Diarrhoeal Disease. Website Http://Http://Www.Who.Int/Mediacentre/Factsheets/Fs330/En/Diakses Pada Tanggal 29 Januari 2018. 